\title{
Kohaliku mälu säilitamine - püha jumalaema kultus
}

\author{
Milena Ljubenova \\ Bulgaaria Teaduste Akadeemia Etnoloogia ja Folkloori Uurimise \\ Instituudi koos Etnograafiamuuseumiga abiprofessor \\ milena.lyubenova@iefem.bas.bg
}

\begin{abstract}
Teesid: Käesolev artikkel keskendub neitsi Maarja kultusele Bulgaarias Perniki piirkonna Popovo külas ning käsitleb seda, kuidas kombestik aitab säilitada mälestust minevikust ja hoida kogukondlikku identiteeti. Artikkel põhineb sotsialismiaja alguses Bulgaarias Studena veehoidla alale jäänud kahe sunniviisiliselt ümberasustatud küla endiste elanike seas läbi viidud välitöödel. Vaadeldakse mehhanisme, millele toetub Perniki linna Iztoki kvartali nn ümberasustatute ja konkreetselt Popovo küla püha jumalaema kultus ning milline on selle tähendus tänaseni.
\end{abstract}

Märksõnad: Bulgaaria, jumalaema, kollektiivne mälu, traditsioonid

Meelespidamine ja jutustamine on mehhanismid, mille kaudu inimrühmad säilitavad mälestust oma minevikust ja hoiavad kogukondlikku identiteeti. Kõik, mida mäletatakse, on osa möödanikust ja juttude kaudu jõuab see käesolevasse aega. Mälu on "loominguline protsess, mille kaudu kinnistuvad sõnades elu kõige tähtsamad hetked, väärtused, mis annavad sellele mõtte ja sõnumid, mis peavad jõudma ümberkaudseteni” (Koleva 1999: 24). Mälu on üks minevikku suhtumise vormidest, mis aitab seda mõista. See on teatud elukogemuse tulem, säilitab seda kogemust ja osaleb aktiivselt identiteedi ülesehitamises. ${ }^{1}$

Kollektiivne mälu on katkematu mõttevool ja see säilitab minevikust ainult seda, mis on veel elus või suudab elada seda hoidva rühma teadvuses (Halbwachs 1996: 94). ${ }^{2}$ Jan Assmanni meelest on mälu jaoks oluline selle säilimine kommunikatsioonis. Rühma vaatevinklist on see seotud tunnetuse levitamisega, mida rühm ise enda sees oma liikmetega jagab (Assmann 2001: 35). Lisaks sellele on mälu seotud nii aja kui ühise ruumiga. "Iga rühm, kes tahab konsolideeruda, püüab luua ja kindlustada paiku, mis kujutavad endast mitte ainult kohti tema koostoimimiseks vaid on ka tema identiteedi sümboliteks ja mälestuste nurgakiviks. [---] Kollektiivne mäluruum ja -aeg on mõisted, millel on elav side vastava rühma suhtlusvormidega nii tundeliselt kui ka väärtuslikult. See tähendab, et seda saab vaadelda vaid ühe tõelise ja elava rühma vaatevinklist" (Assmann 2001: 37-38). 
Selles kontekstis vaatleme mehhanisme, millele toetub Perniki linna Iztoki kvartali $^{3} \mathrm{nn}$ ümberasustatute ja konkreetselt Popovo küla püha jumalaema kultus ning selle jätkuv tähendus tänaseni. "Ümberasustatute” all nimetatud linnaosas peetakse silmas Krapetsi ja (Vitoško ${ }^{4}$ ) Popovo ${ }^{5}$ külade elanikke Perniki rajoonis, kes asustati sunniviisiliselt ümber seoses Studena veehoidla ehitusega.

Iztoki kvartal loodi 20. sajandi keskel ja see oli otseselt seotud V. I. Lenini nimelise riikliku mustmetallide metallurgiatehase ${ }^{6}$ (praegu Stomana Industry) ehitusega. Samal ajal, aastatel 1953-1955 algas ka Studena veehoidla ehitus Popovo ja Krapetsi külade maadele. Elanike ümberasustamine toimus käskkirja nr 408 alusel, mis avaldati Riigi Teatajas 13. oktoobril 1953 ja kahe küla elanikud ümberasustati vastvalminud metallurgiatehase lähistele. ${ }^{7}$ Neist sai tehase, Studena veehoidla ehituse ja linna söekaevanduste peamine tööjõud.

Ümberasustamine ei meeldinud inimestele ja harjumine uue elukohaga oli vaevaline. Nad kannatasid, et neil ei lubatud oma kodukohta naasta, ja tingimused, milles nad olid sunnitud elama, tekitasid alguses rahulolematust. Minu vestluskaaslane, kes ümberasustamise läbi elas, räägib:

See juhtus viiekümne kolmanda aasta kevadel. Aprillis, mais ja juunis olid ümberasustatud mõlemad külad. Ma olin siis tudeng. Tulin Krapetsi koju käima, aga meie omasid Krapetsis polnud. Läksin jalgsi, tulin siia, küsisin ühelt ja teiselt, kus nad on, millises paneelmajas. Ja mulle siis öeldi, kus, ja ma leidsin nad üles. Pean sulle ütlema, et üldiselt ei võtnud Krapetsi ja Popovo inimesed seda ümberasustamist hästi vastu. [---] Pandi ühte korterisse kaks-kolm peret kokku elama. [---] Vanad inimesed, suur osa neist ei elanud seda üle. Lihtsalt lahkusid [surid - M. L.] enneaegu. Kui nad alguses tulid, siis ei olnud kõigi jaoks tööd. Üks osa töötas kaevanduses. Pärast tehti töökohad Lenini tehases, seal siis hakkasid tööle. [---] Naised muudkui nutsid. Toodi siia, nad polnud ju harjunud. [---] Eriti raske oli inimestele see, et neil aastatel ei lubatud ju üldse sinna mägedesse minna, kus nad elanud olid. (AIF $1 \mathrm{nr}$ 397: 32-33)

Kahe küla elanikud pandi algul elama kolme-neljakorruselistesse paneelmajadesse. Nende juttudes kerkib mälestus igatsusest kodumajade järele ja igapäevaraskustest uues kohas. Ümberasustamisest juttu tehes kuuled repliike nagu:

Inimesed aeti korteritesse nagu kariloomad. Ei olnud leiba, ei olnud vett. Leiva järel seisime sabas Daskalovos, 1953.-1958. aastani oli häda ja viletsus. Tehas oli inimestele väljapääs, see oli neile varjupaik, sealt said oma leiva. (Eraarhiiv 2013) 
Viimane lause viib meid ka ühe teise nendinguni: eakatel inimestel oli raske harjuda uue kohaga ja elada korteris, kuid noored kohanesid kiiremini. See omakorda provotseerib rääkima linna uusrajoonidest ja selle heakorrast, mille tulemusel sai piirkonnast Perniki linna kõige suurem linnaosa.

Kahe küla esindajate ja nende järglaste kooselu jätkub Iztoki kvartalis praeguse ajani. Pärast esialgset ümberasustamist uutesse paneelmajadesse toimus mõne aasta jooksul uus kolimine. Osale inimestest, kes soovisid endale maja ehitada, anti maatükid, kuhu nad need ehitada võisid. See osa linnaosast sai tuntuks kui ümberasustatute majad.

Ümberasustamine, keeld külastada oma külade maid ja inimeste vajadus kohaneda uute tingimustega on põhjus, miks hakati otsima uusi kompensatsioonimehhanisme, millega säilitada kogukonna elu ja mälestust kahe küla minevikust. Prantsuse filosoofi Maurice Halbwachsi arvates suudab iga rühm, kes on üle elanud, ümberasustamisega seotud muutuse, "leida uutes oludes oma kunagise tasakaalu. Ta suudab püsima jääda või muutuda antud piirkonnas või tänaval, mis tervikuna ei kuulu enam talle" (Halbwachs 1996: 154). Mõlemale kohalikule kogukonnale oli tähtis säilitada oma identiteet uues töölisrajoonis, kuhu sotsialismi ajal koliti palju inimesi kogu riigist. Kahe minevikuküla elanikud muutusid sotsiaalses ja ühiskondlikus plaanis aktiivseks rajoonikeskuse ülesehitamisel ja heakorrastamisel. ${ }^{8}$

\section{Püha jumalaema - Popovo küla kaitsja}

Ümberasustamisest tänase päevani on ümberasustatute kohaliku mälu ja identiteedi säilitamise tähtis tegur olnud Popovo küla püha jumalaema kultus ja sellega kaasnev jumalaema uinumise püha tähistamine kogu 60 aasta vältel mitte ainult Popovo, vaid ka Krapetsi elanike poolt. Antropoloog Joël Candau peab kollektiivse mälu tähtsaks raamiks kalendrit, mis on vahendaja "läbielatud ja universaalse aja vahel” (Ricoeur' järgi 1985). "Indiviidi jaoks ei ole see ainult igapäeva mälu (minevik ja tulevik), vaid varakamber, kus säilitatakse jagatud mälu religioossetest ja ilmalikest pühadest, tähtsatest sündmustest, tähistamistest ja aastapäevadest" (Candau 2001: 41).

Popovo elanike pühade kalendris on tähtis koht rukkimaarjapäeval. Jumalaema Uinumise kirik ehitati Popovo küla lähistele 1845. aastal. See oli ühekojaline ühe apsiidi ja eeskojaga kirik. Kiriku ikonostaasi ikoonid maalis Nikola Obrazopisov ja eeskojas oli paar Kosta Antikarovi freskot 1878. aastast (Nikolova \& Stojanov-Georev 2003: 27).

Rukkimaarjapäev (vana kalendri järgi 28. august) oli Popovo küla kõige suurem püha, mil korraldati traditsioonilist külapidu. Oreška Angelova räägib: 
Meie kirik oli väga suur, väga ilus. Krapetsist tulid inimesed meie kirikusse. [---] Selle nimi oli Püha Jumalaema, ja siis oli pidu, külapidu. Meie kirik oli seest väga ilus. (AIF $1 \mathrm{nr} 397$ : 58-59)

Jordan Nikolov räägib:

Inimesed katsusid jumalaema pühaks põllutöödega lõpule saada. [---] Olid siis rahulikud ja valmistusid külapeoks. Külapidu oli väga pidulik asi. Teistest küladest tulid sugulased, lähedased. Ja muidugi peeti kirikus ikka jumalateenistus kõigi nende tseremooniatega. [---] See oli kõige suurem pidu. (Eraarhiiv 2015a)

Pidulikule liturgiale kirikus järgnes protsessioon küla keskele, kus toimus ohvrilooma pühitsemine. Ohvriloomi andsid mõned pered külas. Pärast ohvritoidu laialijagamist algas suur külapidu. Peole tulid inimesed ka ümberkaudsetest küladest - Krapetsist, Kladnitsast, Bosnekist, Tšuipetlovost, Studenast, Rudartsist.

2015. aastal rääkisin paari Krapetsi küla naisega, kes olid tulnud Jumalaema uinumise pühal Popovosse ohvririitusele. Nad ütlesid, et olid käinud ka lastena peol ja kirikus:

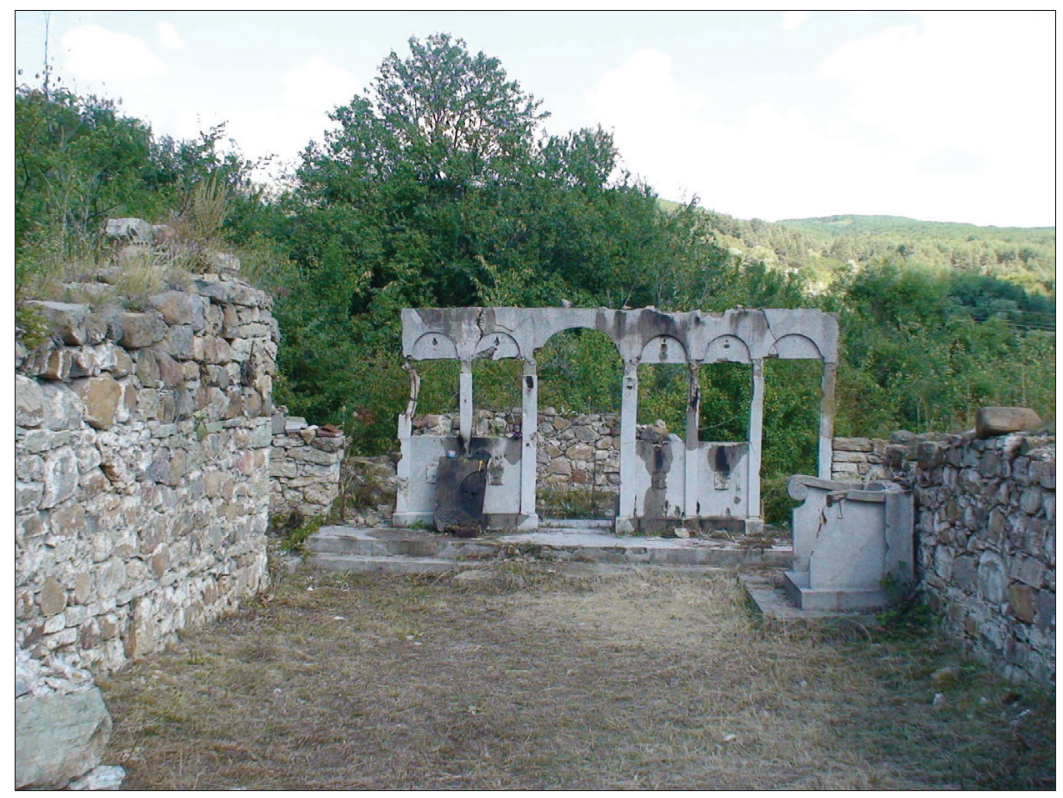

Foto 1. Jumalaema Uinumise kiriku varemed Popovo külas 31. augustil 2013. FtAIF 1387, sü 20. 
Käisime alati Jumalaema pühal aablatit söömas, nagu meie kandis öeldakse. Ma olen siin tihti käinud, sest mu tädi elas siin. Siin on alati külapidu olnud ja palju rahvast. Seda ma mäletan. [---] Istusime kirikus, kuulasime, kuidas papp pühakirja loeb, põletasime küünlaid. [---] Ei tea, miks nad selle kiriku maha lammutasid?! Vesi siia ju üldse ei jõudnud. Meie oma Krapetsis oli vee ääres, selle lammutasid. Aga miks nad selle siis lammutasid? (Eraarhiiv 2015b)

Kuigi kirik ei jäänud veehoidla territooriumile, lammutati ja lõhati see pärast külaelanike ümberasustamist 1953. aastal. ${ }^{9}$

Ümberasustamisega kaotati peaaegu kõik inimeste sünnikohta tagasipöördumise võimalused - majad ja kirik lõhati, ühiskondlikest hoonetest jäi alles ainult endine kooperatiivihoone, mis hiljem anti Riikliku Jahindusseltsi VitošaStudena käsutusse. Minu vestluskaaslaste sõnutsi: "valvati püssidega, ei lastud sammugi sinnapoole minna" (AIF 1 nr 397: 33). Kuni 1960. aastateni ei olnud inimeste juurdepääs sinna kanti nii rangelt keelatud, pärast ümberasustamist olevat naised hingede päeval käinud oma esivanemate kalmudel. Pärast jahimaja ehitamist piirati aga ligipääsu ja ümberasustatutel keelati küla maadele minek.

\section{Peo transformeerumine}

J. Candau järgi on ühe paiga hävitamise eesmärk alati mälu hävitamine eesmärk, mis ei ole teostatav seni, kuni on elus kas või üks selle mälu kandja (Candau 2001: 116). Ajavahemikus 1956-1958 eraldati Iztoki kvartali ümberasustatutele maa individuaalelamute ehitamiseks, osa neist kolis korterist oma majja. Sel ajal ehitati rajooni ka Jumalaema Uinumise kirik - "meie inimestele ja meie inimeste poolt, samasugune, nagu oli vana kirik mägedes" (Hristov \& Manova 2007: 18). ${ }^{10}$

Inimeste juttude järgi ei piisanud uue kiriku ehitamiseks rahast, mis maksti pärast ümberasustamist Krapetsi ja Popovo kiriku lammutamise hüvituseks, ja seetõttu korraldati täiendavaid korjandusi. Jumalaema Uinumise kirikut linnarajoonis peeti justkui kahe küla kirikute - Popovo Jumalaema Uinumise kiriku ja Krapetsi küla Püha Nikolai kiriku - järglaseks. Uue kiriku esimeseks õpetajaks sai mõlemas vanas kirikus teeninud isa Ivan Krapetsi küla Bradvarskite suguvõsast.

Alguses paar aastat kogunesid ümberasustatud jumalaema uinumise pühal kvartali uude kirikusse, kus toimus ka looma ohverdamine. Pärast ohverdamisriituse keeldu religioossel pühal otsustasid mõned naised hakata seda sooritama Živkovi aasa ${ }^{11}$ nimelises paigas kohe pärast jumalaema uinumise püha, 
septembri esimesel nädalal. Osaliste juttude järgi ei leidnud ka see ettevõtmine heakskiitu ja mõned naistest loobusid sellest (Hristov \& Manova 2007: 19; Hristov 2010: 41). Nii lõppeski ohvririituse traditsioon, aga külapidu korraldati sealsamas nurmel lõbustuste ja piduliku eeskavaga kogu sotsialismiperioodil.

Pärast 1989. aasta poliitilisi muutusi Bulgaarias algas algas maade tagastamine kahest külast ümberasustatutele. Inimestele anti maad tagasi, kuid ilma õiguseta sinna ehitada. Suur osa Popovo küla maadest ei jäänud Studena veehoidla alla, mis võimaldas selle endistel elanikel otsida võimalusi sinna tagasi pöörduda. Hakati ehitama kuure ja paigutama aiamaadele soojakuid. Mõned vanemad inimesed hakkasid veetma suve oma kodukülas. Varsti pärast poliitilisi muutusi korraldati Popovos suguvõsade kokkutulek. Ürituse tunnistaja rääkis, et kui inimesed jõudsid küla piirile, andsid mõned vanad inimesed maale suud.

Popovo elanike initsiatiivil hakati alates 1993. aastast jumalaema uinumise püha tähistama jälle küla maadel. 2001. aastal võttis algatusrühm ${ }^{12}$ vastu otsuse kirik taastada. Algas hävitatud kiriku varemete puhastamine.

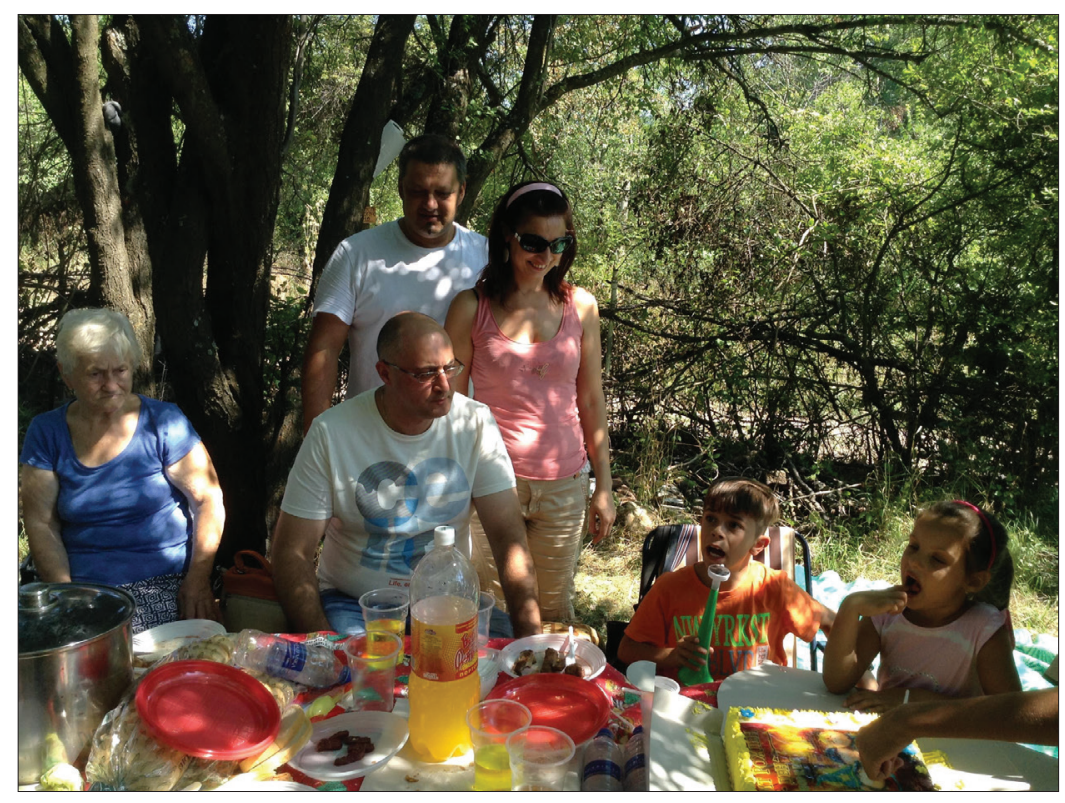

Foto 2. Suguvõsa kokkutulek Popovos 29. augustil 2015. FtAIF 1449, sü 52. 


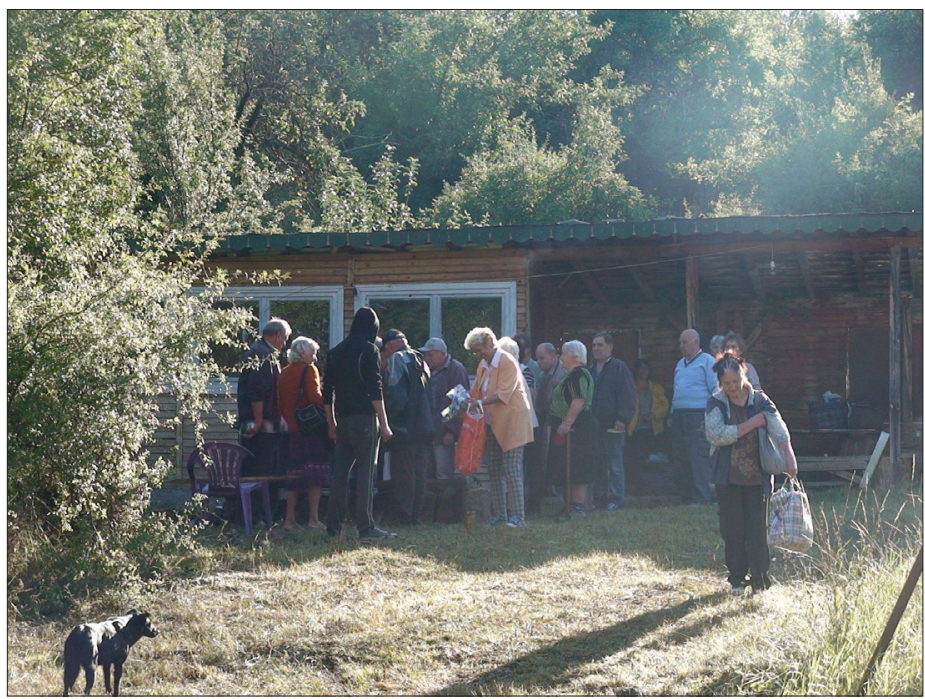

Foto 3. Rituaalse toidu jagamine Popovo külas 31. augustil 2013. FtAIF 1387, sü 1.

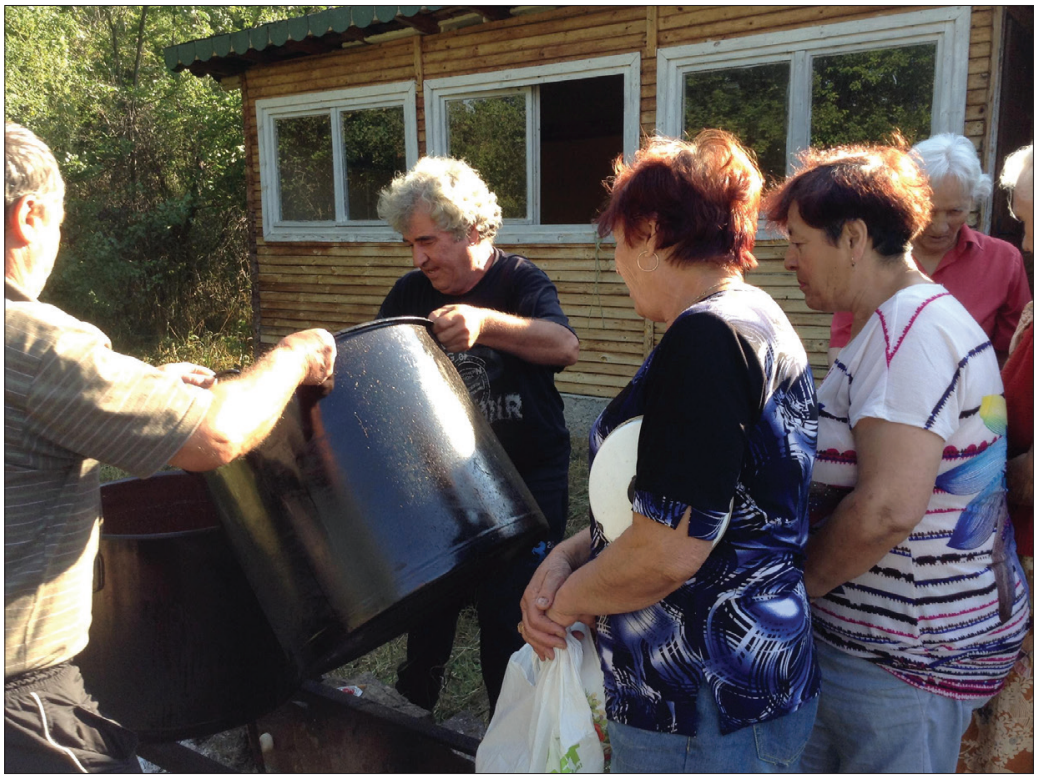

Foto 4. Toidujagamise rituaal Popovo külas 29. augustil 2015. FtAIF 1449, sü 5. 


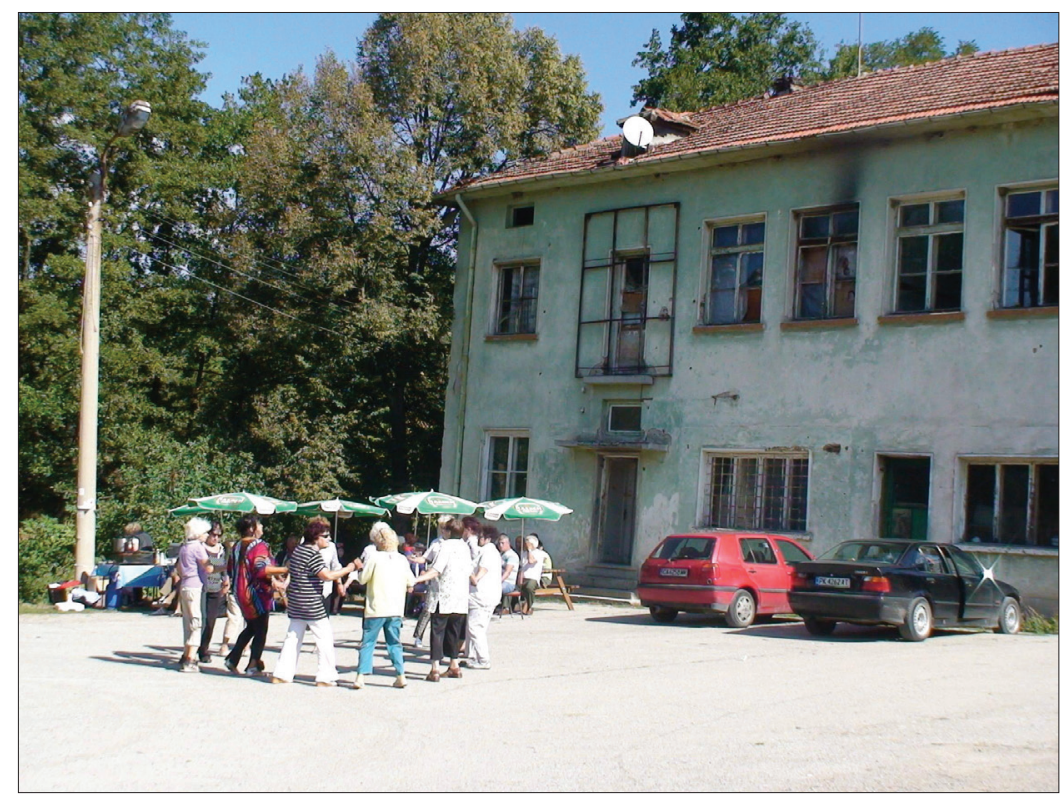

Foto 5. Tantsusõõr Popovos kunagise kooperatiivihoone ees 31. augustil 2013. FtAIF 1387, sü 4.

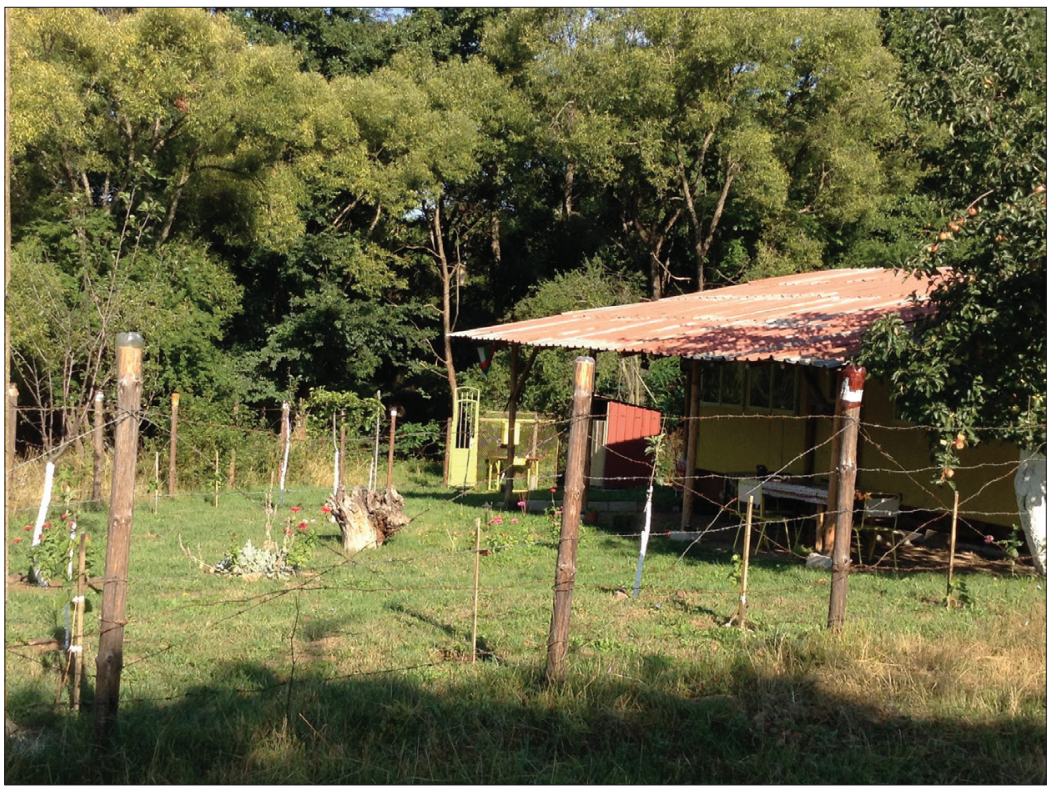

Foto 6. Varjualusega õuemaa Popovos. FtAIF 1449, sü 24. 
Pärast 2000. aastat toimus ohvritalituse pühitsemise osa mõnda aega kiriku varemete juures ja pidu endise kooperatiivihoone esisel platsil. Pidupäeval käisid mõned inimesed kiriku varemetel ja süütasid seal küünlaid. Ohvriloomast valmistati toit, mis jagati inimestele peopaiga lähedusse selleks spetsiaalselt ehitatud puidust suveköögis. Tantsiti endise kooperatiivi ees platsil. Osa inimesi jäi laagrisse platsi lähedale, teine osa läks oma maadele soojakutesse ja kuuridesse, kus nad said kokku sugulastega või varjusid puude alla oma endistel ouemaadel.

Nii suutis püha jumalaema kultus hoolimata muutlikest aegadest ja külakogukonnale kaela langenud raskustest olla katalüsaatoriks kogukonna püüdlusele säilitada kohalikku mälu ja identiteeti. Popovo küla Jumalaema Uinumise kiriku varemed ja külapidu muutusid ajapikku ümberasustatute mälestuste tugisammasteks ja kannab tänapäeval mälupaiga tähendust (Nora 2005 järgi). ${ }^{13}$

\section{Jumalaema uinumise püha Iztoki kvartalis}

Jumalaema uinumise püha Iztoki kvartalis muutus möödunud 60 aasta jooksul terve kvartali pühaks. Rukkimaarjapäeval (15. augustil) tulevad kirikusse praeguseks linna suurimaks elurajooniks kasvanud kvartali elanikud. Hommikul toimub pidulik liturgia ja pärast seda jagatakse kiriku aias ohvriloomast valmistatud toitu. Paljud inimesed on valinud jumalaema uinumise püha oma laste ristimise päevaks.

Viimased 15 aastat saadab kirikupüha ka lõbus pidu kiriku lähedal. Sellest võtavad osa ametiisikud, linnaosa ja linnavalitsuse esindajad. Pidulik osa jätkub muusikakava laulude ja tantsudega.

Praegu on kirik pühapaik kõigile Iztoki kvartali elanikele ja jumalaema uinumise pühast on saanud terve kvartali pidu. Ümberasustatud ja nende järglased peavad rukkimaarjapäeva nii uue kui ka vana kalendri järgi: 15. augustil Iztoki kvartalis ja 28. augustil (või sellele kõige lähemal puhkepäeval) külapidu Popovo külas.

Jan Assmanni järgi: "Pidude ja rituaalide tavaeesmärk on järjepideva kordumise kaudu vahendada samastavat teadmist ja sel moel taastekitada kultuurilist identiteeti. Rituaalne kordus tagab rühma koherentsuse ruumis ja ajas" (Assmann 2001: 55). On tõsiasi, et pärast kogu Popovo ja Krapetsi ümberasustamise aega on jumalaema austamine olnud see, mille kaudu on ühes või teises vormis eri perioodide erisugustes tingimustes hoitud elus kogukondliku 


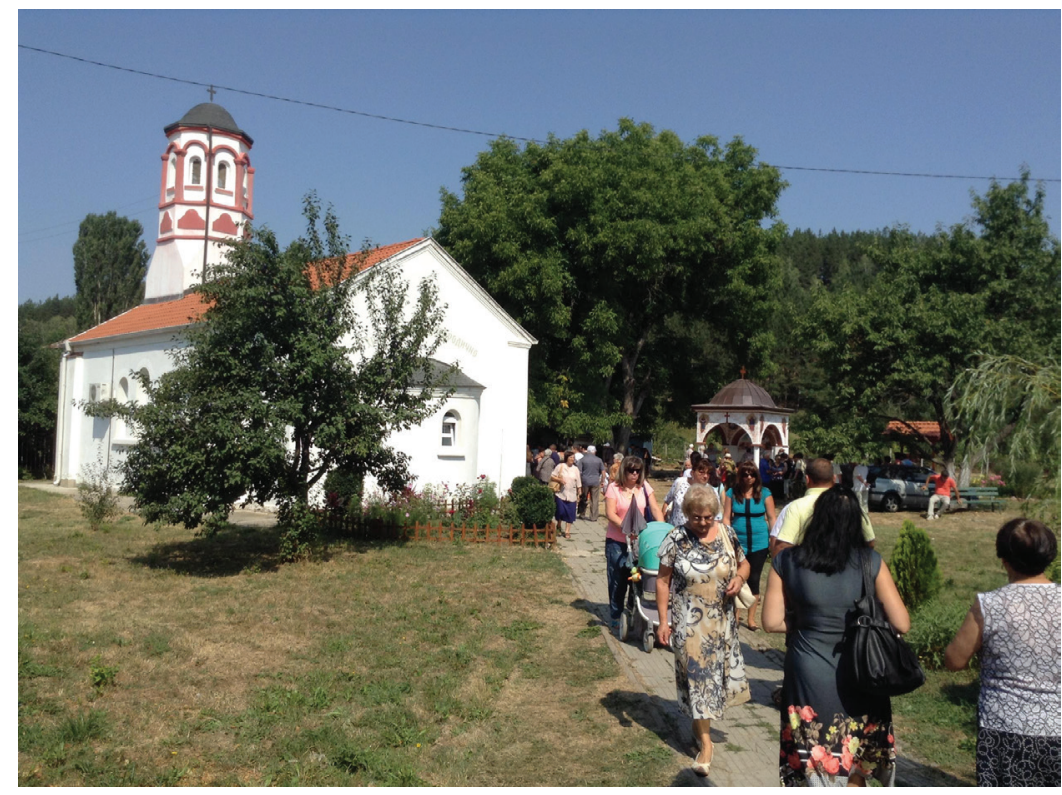

Foto 7. Jumalaema Uinumise kirik Pernikis Iztoki kvartalis 15. augustil 2015. FtAIF 1448, sü 19.

suhtlemise vajadust. See on aidanud kaasa lokaalse mälu säilimisele, kutsudes olevikus esile teadmise kahe küla minevikust ja mõjutades ka järgmiste põlvkondade suhtumist. 1989. aasta poliitilised sündmused ja sellele järgnev (ümberasustatutele maade tagastamine, mõnegi vana aiamaa ülesharimine Popovos, rukkimaarjapäeva ohvrilooma riituse taaselustamine külas) on katalüsaatoriks uutele juttudele külaelust ja ümberasustamisest nii 1950. aastatel need sündmused üle elanute kui ka nende järglaste seas. Popovo küla elustamine kas või üheks päevaks aastas kutsub esile olukorrad, kus räägitakse ja meenutatakse lugusid selle kogukonna minevikust. Vanad inimesed jalutavad oma järglastega ringi ja näitavad neile, kus olid nende õued, majad ja pere varad. Ümberasustatute seas elab ka lootus, et kunagi ärkab küla uuesti ellu. Meenutustes ei taaselustata ainult minevikku, vaid see aitab korraldada ka olevikku ja on suunatud tulevikku.

Jan Assmanni järgi on see, mida ühe rühma või kogukonna liikmed tegelikult jagavad, just see, mille nad oma ühise mineviku kohta unustavad. Kollektiivne mälu tugineb pigem unustamisele kui mäletamisele. Seepärast vajab ühise mälu säilitamine rühmas kordamist. Kordusvajadus ja sobiv säilituskeskkond 
paljastavad ka sotsiaalse ja kollektiivse mäluraamistiku rolli (Assmann 2001: 64-65). Mälestus ühisest minevikust on tähtis mehhanism, mis loob ümberasustatute seas ühtse kogukonna tunde, meenutamine ja jutuvestmine aga kutsuvad esile kollektiivsed püüdlused kogukonda säilitada.

\section{Tõlkinud Wiedemanni Tõlkebüroo}

\section{Kommentaarid}

1 Tähtis roll identiteedi loomisel on individuaalsel ja kollektiivsel mälul. Mälu ja identiteedi vastastikuse seose kohta vt Candau 2001.

2 Kollektiivse mälu kohta vt Halbwachs 1996; Nora 1997.

3 Sotsialismi ajal kandis linnaosa Lenini nime, pärast 1989. aasta poliitilisi muudatusi nimetati see ümber Iztokiks (Ida rajooniks).

4 Krapetsi ja Popovo maad paiknevad Vitoša mäe edelanõlvadel ja Perniki linna (Lääne Bulgaaria) lähedal. Enne ümberasustamist kuulusid külad halduslikult Sofia piirkonna alla. Minevikus olid mõlemad külad tuntud rauamaagi kaevandamise poolest. Elatise teenimise viis muutus aja jooksul ning kaevuritele lisandusid kaubavedajad, möldrid ja loomakasvatajad. Pärast kaevandustegevuse lõppu, juba enne Bulgaaria vabastamist osmani ikkest elatusid need külad peamiselt põllundusest ja loomakasvatusest. Oli ka neid, kes käisid mujal tööd otsimas. 19. sajandi lõpus kasvas külaelanike arv Popovo külas 483 elanikust 1880. aastal 1127 inimeseni 1947. aastal (Penkov 1948: 180) ja Krapetsi küla 431 elanikust samal perioodil 945 elanikuni (Penkov 1948: 184).

5 Vitoško (Srõbski Samokov, Popovo). Küla nimetati ümber Srõbski Samokovist Popovoks 11.02.1887 määrusega nr 44 ja 8.12.1944 määrusega nr 949 nimetati see ümber Vitoškoks (Mitšev 2005: 76).

6 Tehas hakkas tööle 8. augustil 1953.

7 Lisaks Iztoki kvartalile ümberasustati külaelanikud ka Cõrkva (endise küla) rajooni.

8 Ümberasustatud osalesid aktiivselt 1960. aastal Iskra kultuurimaja ja hiljem pensionäride klubi loomisel.

9 2003. aastal dokumenteerisin jutu karistuse kohta, mis järgnes kiriku hävitamisele. Mees, kes hakkas esimesena katusekive maha võtma ja purustas kirikukella, sai kõvasti kannatada. Ühe nädala jooksul suri tema laps ja pärast seda suri ka ta ise, jäädes lume alla (AIF I nr 397: 59).

${ }^{10}$ Autorid osundavad informaatori sõnu.

${ }^{11}$ Paik asub seal, kus ümberasustatute majad.

${ }^{12}$ Algatusrühm loodi eesmärgiga tagastada Popovo külast ümberasustatutele nende maad ja taastada küla.

${ }^{13}$ Mõiste hõlmab füüsilisi ja sümboolseid objekte, tuginedes "sellele, mis asub nende vahel" (Nora 2005: 19). 


\section{Arhiiviallikad}

\section{Bulgaaria Teaduste Akadeemia Etnograafiamuuseumi etnoloogia ja rahvaluule uurimise instituudi arhiivis}

AIF 1 nr 397: 32-33. Informaator: Dimitõr Ilkov, snd 1932 Krapetsi küla, Perniki oblastis (enne Sofia kihelkond). Salvestas M. Ljubenova 25. augustil 2003 Iztoki kvartalis Perniki linnas.

AIF 1 nr 397: 33. Informaator: Dimitõr Ilkov, snd 1932 Krapetsi külas Perniki oblastis (enne Sofia kihelkond). Salvestas M. Ljubenova 25. augustil 2003 Iztoki linnaosas Perniki linnas.

AIF 1 nr 397: 58-59. Informaator: Oreška Angelova, snd 1920 Popovo külas Perniki oblastis (enne Sofia kihelkond). Salvestas M. Ljubenova 22. juulil 2003 Iztoki linnaosas, Perniki linnas.

FtAIF - Fotoarhiiv Bulgaaria Teaduste Akadeemia Etnograagiamuuseumi etnoloogia ja rahvaluule uurimise instituudis, säilikud $\mathrm{nr} 1387$, a.e. $1,4,20 ; 1448$, a.e. 19 ja 1449 , a.e. $5,24,52$.

\section{Autori eraarhiivis}

Eraarhiiv 2013. Informaator Jordan Nikolov, snd 1932 Popovo külas Perniki oblastis (enne Sofia kihelkond). Salvestas M. Ljubenova 21. augustil 2013 Iztoki kvartalis, Perniki linnas.

Eraarhiiv 2015a. Informaator Jordan Nikolov, snd 1932 Popovo külas Perniki oblastis (enne Sofia kihelkond). Salvestas M. Ljubenova 25. septembril 2015 Iztoki linnaosas, Perniki linnas.

Eraarhiiv 2015b. Informaator Manka Bratoeva, snd 1937 Krapetsi külas Perniki oblastis (enne Sofia kihelkond). Salvestas M. Ljubenova 29. augustil 2015 Popovo külapeol.

\section{Kirjandus}

Assmann 2001 = Asman, Ian. Kulturnata pamet. Pismenost, pamet i politicheska identichnost $v$ rannite visokorazviti kulturi. Sofia: Planeta.

Candau 2001 = Kando, Zhoel. Antropologiia na pametta. Vratsa: Odri.

Halbwachs 1996 = Khalbvaks, Moris. Kolektivnata pamet. Sofia: Kritika i khumaniz"m.

Hristov \& Manova 2007 = Khristov, Petko \& Manova, Tsvetana. Noviiat "star" kurban. Karamikhova, Margarita (koost). "Zavr”shchane" na religioznostta. Academica Balkanica 3. Sofia: BAN Etnografski institut s muzei, lk 11-30. 
Hristov 2009-2010 = Khristov, Petko. Seloto na furgonite. Natsionalniia istoricheski konkurs 2009-2010 g. Pametni mesta, s"bitiia, lichnosti-pochitani, otrecheni, zabraveni. Sofia, lk 40-41.

Koleva 1999 = Koleva, Daniela. Zhiteiskiiat razkaz - nachin na upotreba. Koleva, Daniela \& Gavrilova, Raina \& Elenkova, Vania (koost). Sl"ntseto na zalez pak sreshchu men. Zhiteiski razkazi. Sofia: Lik, lk 7-30.

Ljubenova 2015 = Liubenova, Milena. Industrializatsiiata na grad Pernik i izselvaneto na selata Krapets i Popovo - prezhiviavane, pamet, narativi. Chadžijski, Boris (koost). Grad i pamet. Sbornik s dokladi ot Vtora natsionalna nauchna konferentsiia, provedena v Pazardzhik, 5-6 iuni 2014 g. Pazardzhik, lk 94-99.

Mitšev 2005 = Michev, Nikolai. Rechnik na imenata $i$ statuta na naselenite mesta v B"lgariia 1878-2004. Sofiia: Pet"r Beron.

Nikolova \& Stojanov-Georev 2003 = Nikolova, Mariiana \& Stoianov-Georev, Pet"r. Popovo. Zavr"shchane v bashchinite k"shchi. Pernik.

Nora 1997 = Nora, Pier. Kolektivnata pamet. Deianova, Liliana (koost). Dukh"t na Anali. Sofia: Kritika i khumaniz"m, lk 233-237.

Nora 2005 = Nora, Pier. Mesta na pamet: Ot arkhiva do emblemata. 2 . kd. Sofia: Dom na naukite za choveka i obshchestvoto.

Penkov 1948 = Penkov, Ignat. Stopansko-geografska kharakteristika na raiona Dragichevo - Pernik - Batanovtsi. Sofiia: Universitetska pechatnitsa.

\title{
Summary
}

\section{Maintaining local memory: The cult of the Virgin Mary}

\author{
Milena Lyubenova \\ Assistant Professor \\ Institute of Ethnology and Folklore Studies with Ethnographic Museum \\ Bulgarian Academy of Sciences
}

Keywords: Bulgaria, collective memory, Mother of God, traditions

The article focuses on the cult of the Virgin Mary in the village of Popovo, Pernik region, and the way that cult becomes a factor in maintaining the local memory of the community that experienced traumatic changes in Bulgaria at the beginning of the socialist period. The villages of Popovo and Krapets were displaced because of the intensive industrialization of the Pernik region in the early 50s of the twentieth century and the building of the Studena dam. The population was moved near the newly-built state-owned metallurgical plant named after V.I. Lenin (now Stomana Industry), where the building of the largest quarter of the town started. Access was prohibited to the villages and the settlers' need to adapt to the new conditions resulted in looking for compensatory mechanisms in maintaining the community life and local memory of the 
two previous settlements. The building of the Dormition of the Virgin Mary Church in the new quarter named after Lenin (now Iztok) is perceived as a kind of continuation of the destroyed village churches, and its patron saint's day is celebrated up to the very present by the previous inhabitants of Popovo and their descendants. The study is based on field research among the settlers from the two villages, as well as on observations on the restored village feast in Popovo after 1989, and on the celebrations of the Day of the Virgin Mary in the Iztok quarter of Pernik.

Milena Ljubenova on Bulgaaria Teaduste Akadeemia Etnoloogia ja Folkloori Uurimise Instituudi koos Etnograafiamuuseumiga abiprofessor. Ta on Bulgaaria Mittemateriaalse Kultuuripärandi Riikliku Keskuse juhataja. Varasemad tööd on keskendunud suulisele ajaloole, folkloorimaterjalide kogumisele ja säilitamisele. Tema praegune töö on keskendunud vaimse kultuuripärandi kaitsele, kohaliku ajaloo ja kultuuri, kollektiivse mälu ja identiteetide uurimisele.

Milena Lyubenova, PhD, is Assistant Professor at the Institute of Ethnology and Folklore Studies with Ethnographic Museum, Bulgarian Academy of Sciences. She is head of the National Center for Intangible Cultural Heritage. Her past work focused on oral history, collecting and preserving of the folklore materials. Currently she focuses on the safeguarding of intangible cultural heritage, local history and culture, collective memory and identities.

milena.lyubenova@iefem.bas.bg 